DOI: https://doi.org/10.24127/ajpm.v10i2.3545

\title{
BELAJAR BERSAMA COVID-19:REVIEW IMPELEMENTASI, TANTANGAN DAN SOLUSI PEMBELAJARAN DARING PADA GURU-GURU SMP
}

\author{
Ratni Purwasih $^{1 *}$, Dewi Safitri Elshap ${ }^{2}$ \\ ${ }^{1 *, 2}$ IKIP Siliwangi, Cimahi, Indonesia \\ *Corresponding author. \\ E-mail: $\quad \frac{\text { ratnipurwasih@ikipsiliwangi.ac.id }}{{ }^{1 *}}$ \\ nouradewi14@yahoo.com $^{2}$
}

Received 09 February 2021; Received in revised form 28 June 2021; Accepted 03 July 2021

\begin{abstract}
Abstrak
Adapun tujuan dari penelitian ini adalah untuk mengetahui implementasi pembelajaran dalam jaringan (daring) serta tantangan apa saja yang menjadi pendukung dan penghambat guru dalam proses pembelajaran daring untuk guru sekolah menengah pertama dan solusinya. Metode penelitian yang digunakan adalah kualitatif deskriptif dengan pengambilan sampel secara purposive sampling. Teknik pengumpulan data melalui kuesioner dan wawancara terstruktur. Subjek penelitian ini adalah 28 guru matematika yang mengajar di berbagai sekolah di Kabupaten Bandung, Jawa Barat. Metode penelitian yang di gunakan adalah deskriptif kualitatif. Instrumen penelitian ini adalah wawancara dan kuisioner melalui google form. Teknik pengumpulan data yang digunakan dalam penelitian ini berupa angket terbuka, wawancara terstruktur dan dokumentasi. Langkah-langkah penelitian meliputi pengumpulan data, reduksi data, penyajian data dan penarikan kesimpulan. Hasil penelitian menunjukkan bahwa guruguru matematika dalam implementasi pembelajaran menggunakan berbagai platform media sebagai alat bantu pembelajaran daring seperti google meet, google classroom dan E-learning; , respon siswa terhadap pembelajaran daring yaitu postif serta pembelajaran daring memiliki tantangan/kendala, baik dari aspek sumber daya manusia, sarana-prasarana, dan teknis implementasinya.
\end{abstract}

Kata kunci: Covid-19; guru; pembelajaran daring.

\begin{abstract}
The purpose of this research is to find out the implementation of online learning as well as what challenges are the supporters and obstacles for teachers in the online learning process for junior high school teachers and their solutions. The research method used is descriptive qualitative with purposive sampling. Data collection techniques through questionnaires and structured interviews. The subjects of this study were 28 mathematics teachers who teach in various schools in Bandung Regency, West Java. The research method used is descriptive qualitative. The research instrument is interviews and questionnaires via google form. Data collection techniques used in this study were open questionnaires, structured interviews and documentation. The research steps include data collection, data reduction, data presentation and conclusion drawing. The results show that mathematics teachers in implementing learning use various media platforms as online learning aids such as google meet, google classroom and E-learning; students' responses to online learning are positive and online learning has challenges/obstacles, both from the aspect of human resources, infrastructure, and technical implementation.
\end{abstract}

Keywords: Covid-19; teacher; online learning.

This is an open access article under the Creative Commons Attribution 4.0 International License

\section{PENDAHULUAN}

Salah satu negara yang terjangkit Covid-19 adalah Indonesia. Untuk memutuskan mata rantai penyebaran
COVID-19 diperlukan kerjasama semua pihak dalam mengatasinya. Covid-19 berpengaruh ke semua sektor kehidupan, khususnya dunia 
pendidikan. Untuk mengurangi penyebaran virus Covid-19 ini, pemerintah mengambil sikap menutup sementara aktivitas pendidikan. Peran pendidikan di era pandemik sangat penting, dimana siswa atau pun guru bisa saja berperan sebagai penyebar atau pembawa virus Covid-19 tanpa gejala. Oleh karena itu, Kementerian Pendidikan dan Kebudayaan Republik Indonesia dengan tegas memberlakukan kebijakan pembelajaran daring Pembelajaran dilakukan dari rumah secara daring dengan menggunakan aplikasi seperti whatapps grup, google meet, google classroom dan e-learning. Menurut (Imania \& Bariah, 2019), pembelajaran daring merupakan bentuk penyampaian pembelajaran konvensional yang dituangkan pada format digital melalui internet. Pembelajaran daring, dianggap menjadi satu-satunya media penyampai materi antara guru dan siswa, dalam masa darurat pandemi.

Pelaksanaan sekolah dari taman kanak-kanak hingga universitas yang di tutup berdampak pada sistem belajar mengajar. Perubahan pelaksanaan pembelajaran yang awal mula dari dalam kelas hingga pelaksanaannya dalam jaringan (daring). Guru berperan penting sebagai pengendali dalam proses pembelajaran (Basilaia \& Kvavadze, 2020). Pembelajaran daring yang dilaksanakan secara massal di era covid-19 merupakan uji coba yang dapat memberikan gambaran secara utuh dan membuat pemerintah dan lembaga pendidikan harus mencari cara agar pendidikan tetap berjalan secara baik. Dampak negatif maupun positif pembelajaran daring memberikan kesempatan bagi pemangku kebijakan untuk mengevaluasi secara detail dan terperinci dalam mengambil kebijakan berikutnya. Pengaplikasian pembelaja- ran daring ini adalah bukti dari revolusi industri 4.0, dimana pengaksesan teknologi tidak terbatas, sehingga memungkinkan pelaksanaan pembelajaran daring atau jarak jauh.

Pandemi Covid-19 memberikan kesempatan guru untuk mampu beradaptasi dengan teknologi. Guru harus siap dengan berbagai kondisi pembelajaran dan kondisi siswa untuk memberikan arahan, bimbingan, melatih, memberikan penilaian dan evaluasi. Pandemi Covid-19 ini kiranya bisa menjadi pintu masuk untuk merubah paradigma proses belajar yang peka terhadap teknologi. Melalui pandemi Covid-19, bangsa ini belajar untuk memanfaatkan dan mengoptimalisasikan kinerja berbagai sektor kehidupan terutama sektor pendidikan.

Beberapa penelitian berkaitan dengan review implementasi pembelajaran daring di sekolah menunjukkan aneka ragam hasil baik segi platform pembelajaran daring yang dipergunakan, respon postif siswa, tantangan atau kendala dari aspek sumber daya dan sarana. Berbagai platform digunakan dalam pembelajaran daring, sementara guru, peserta didik, dan orang tua diharapkan terus melakukan penyesuaian seiring berjalannya waktu. Berbagai respon positif disampaikan peserta didik terkait pembelajaran daring karena dirasa lebih santai, menyenangkan, fleksibel, efisien, singkat, praktis, cepat, tepat, aman, mudah, hemat waktu, dan hemat tenaga (Wahyono et al., 2020).

Berbagai platform digunakan dalam pembelajaran daring, sementara guru, peserta didik, dan orang tua diharapkan terus melakukan penyesuaian seiring berjalannya waktu. Berbagai respon positif disampaikan peserta didik terkait pembelajaran daring karena dirasa lebih santai, menyenangkan, 
fleksibel, efisien, aman, singkat, praktis, cepat, tepat, mudah, dan hemat waktu serta tenaga. Pembelajaran dapat dilakukan secara jarak jauh, sehingga membuat orang tua bisa mengawasi anaknya belajar, membuat peserta didik menjadi melek teknologi, dan lebih kreatif (Jamilah, 2020). Sedangkan (Waruwu, 2020), pembelajaran daring di Sekolah Dasar selama pandemik COVID-19 mampu meningkatkan pengetahuan, keterampilan, penguasaan teknologi, otonomi, kreativitas, kemandirian peserta didik dan menunjukkan kesiapan institusi sekolah baik guru maupun fasilitas untuk melaksanakan pembelajaran jarak jauh.

Perubahan pola belajar dan mengajar tentu tak akan pernah terlepas dari peran guru terlebih perubahan ke pola pembelajaran daring. Guru adalah individu yang berhadapan langsung dengan peserta didik di kelas dalam pembelajaran. Guru memiliki peran penting untuk membuat peserta didik berkualitas baik akademis, keahlian, kematangan emosional, moral serta spiritual. Guru sebagai garda terdepan dalam implementasi pembelajaran terutama di era Covid-19 ini. Sehubungan dengan itu, artikel ini bertujuan untuk mengetahui implementasi pembelajaran dalam jaringan (daring) serta tantangan apa saja yang menjadi pendukung dan penghambat guru dalam proses pembelaja-ran daring untuk guru SMP dan solusinya.

Urgensi dilakukan penelitian ini karena review pembelajaran daring di sekolah dasar sudah ada sedangkan review pembelajaran daring pada guruguru di sekolah menengah pertama di kab. Bandung belum ada. Penelitian ini akan dikembangkan berkaitan dengan implementasi, tantangan dan solusi pembelajaran daring pada guru-guru SMP di Kab. Bandung.
Berdasarkan uraian di atas, tujuan penelitian ini adalah mengetahui implementasi pembelajaran dalam jaringan (daring) serta tantangan apa saja yang menjadi pendukung dan penghambat guru dalam proses pembelajaran daring untuk guru sekolah menengah pertama dan solusinya

\section{METODE PENELITIAN}

Jenis penelitian yang digunakan adalah deskriptif kualitatif. Hasil penelitian kualitatif di ranah pendidikan bersifat deskriptif. Dalam memilih subjek penelitian, menggunakan teknik purposive sampling. Sehingga di peroleh 28 guru matematika sekolah menengah pertama dari 8 sekolah di Kab.Bandung.

Teknik pengumpulan data yang digunakan dalam penelitian ini adalah berupa angket atau kuesioner, wawancara, dan dokumentasi. Jenis angket yang digunakan adalah angket terbuka dan fase kuesioner, menggunakan seluruh pertisipan yang dijelaskan sebelumnya untuk mengumpulkan data. Adapun untuk instrumen yang digunakan pada fase ini yakni angket yang dapat diakses secara online melalui google form. Jenis wawancara yang digunakan dalam penelitian ini berupa wawancara terstruktur. Wawancara digunakan untuk menggali informasi terkait tanggapan guru terhadap pembelajaran daring dan dokumentasi digunakan untuk mendokumentasikan pembelajaran daring yang dilaksanakan oleh guru-guru SMP selama proses penelitian untuk mendukung penelitian. Tahap analisis data dilakukan dengan cara mengorganisasikan data hasil penelitian sesuai dengan tujuan penelitian yaitu mengidentifikasi dan mendeskripsikan review implementasi, tantangan dan solusi pembelajaran 
daring pada guru-guru SMP. Pada tahap akhir dilakukan penarikan kesimpulan berdasarkan hasil analisis data. Kesimpulan akhir yang diperoleh dikemas sedemikian rupa sehingga diperoleh informasi yang tercantum pada bagian hasil dan pembahasan penelitian.

\section{HASIL DAN PEMBAHASAN}

Untuk memperoleh data tentang implementasi pembelajaran daring di sekolah melalui angket. Berdasarkan angket terbuka dan wawancara terstruktur yang dilakukan secara daring diperoleh informasi untuk mereview implementasi pembelajaran daring di sekolah tersebut. Angket tersbeut disebarkan secara daring melalui google form, sedangkan untuk wawancara dilakukan menggunakan whatsapp dan google form. Adapun hasil penelitian yang diperoleh dalam penelitian ini adalah merujuk ke Tabel 1 .

Tabel 1. Pertanyaan angket

\begin{tabular}{|c|c|c|}
\hline \multirow[t]{2}{*}{ Pertanyaan } & \multicolumn{2}{|c|}{$\begin{array}{l}\text { Jawaban } \\
\text { Responden }\end{array}$} \\
\hline & Ya & Tidak \\
\hline $\begin{array}{l}\text { Apakah pembelajaran } \\
\text { daring atau online } \\
\text { dilaksanakan di sekolah } \\
\text { Anda }\end{array}$ & $\begin{array}{l}89,3 \\
\%\end{array}$ & $\begin{array}{l}10,7 \\
\%\end{array}$ \\
\hline $\begin{array}{llr}\text { Apakah Anda } & \text { sebagai } \\
\text { guru sudah } & \text { siap } \\
\text { menghadapi } & \\
\text { pembelajaran } & \text { secara } \\
\text { daring. } & \end{array}$ & $\begin{array}{l}82,1 \\
\%\end{array}$ & $\begin{array}{l}17,9 \\
\%\end{array}$ \\
\hline $\begin{array}{l}\text { Apakah guru menguasai } \\
\text { teknologi dalam system } \\
\text { yang digunakan dalam } \\
\text { pembelajaran daring }\end{array}$ & $\begin{array}{l}85,7 \\
\%\end{array}$ & $\begin{array}{l}14,3 \\
\%\end{array}$ \\
\hline $\begin{array}{l}\text { Apakah pelaksanaan } \\
\text { pembelajaran daring } \\
\text { dilakukan sesuai waktu } \\
\text { yang terjadwal setiap } \\
\text { mata pelajaran yang } \\
\text { telah disepakati dengan } \\
\text { guru. }\end{array}$ & $\begin{array}{l}92,9 \\
\%\end{array}$ & $7,1 \%$ \\
\hline
\end{tabular}

Pembelajaran daring yang dilaksanakan di sekolah memberikan kesempatan kepada siswa dan guru untuk beradaftasi dengan teknologi. Teknologi diciptakan untuk memudahkan aktivitas manusia, termasuk proses belajar. Namun, pada saat pembelajaran daring dilaksanakan tentunya muncul permasalahan yang dihadapi siswa. Fakta dilapangan menunjukan bahwa 10,7\% pembelajaran tidak dilaksanakan secara daring. Tentunya, ada faktor penghambat dalam implementasi pembelajaran daring. Hal ini sejalan dengan (Purwanto et al., 2020), kendala pembelajaran daring yaitu pembelian kuota dan peran orang tua mendampingi anak tentunya bukan hal yang mudah untuk dilakukan,terutama bagi orang tua yang aktivitasnya berkerja.

Kompetensi guru dalam menggunakan teknologi akan mempengaruhi kualitas kegiatan belajar mengajar. Adanya wabah Covid-19 memaksa para guru harus menggunakan teknologi, sehingga suka tidak suka dan mau tidak mau harus belajar dan siap mengajar melalui jarak jauh dengan menggunakan teknologi. Namun, fakta dilapangan $17,9 \%$ masih ada guru yang belum siap untuk melaksanakan pembelajaran daring. Metode pembelajaran daring membuat guru perlu waktu untuk beradaptasi menghadapi perubahan kurikulum yang disesuaikan dengan kondisi Covid-19. Fenomena dilapangan $14,3 \%$ guru belum menguasai teknologi yang digunakan dalam pembelajaran. Menurut (Chakraborty \& Muyia Nafukho, 2014), mengungkapkan beberapa faktor yang dapat menciptakan pengalaman belajar yang menarik bagi pembelajar online, diantaranya memberikan umpan balik yang konsisten secara tepat waktu; dan 
menggunakan teknologi yang tepat untuk mengirimkan konten yang tepat.

Pembelajaran

daring menyebabkan guru sulit untuk berpindah dari materi yang satu ke materi yang berikutnya, namun guru mengusahakan pemberian tugas disesuaikan dengan buku pegangan peserta didik dan guru. Pada saat sekarang ini guru sangat diperlukan karena walaupun peserta didik belajar dirumah, guru harus tetap mengajar, karena guru mempunyai peranan yang amat strategis dan penting dalam keseluruhan upaya pendidikan. Hampir semua usaha pembaharuan di bidang kurikulum dan penerapan metode mengajar guru, pada akhirnya tergantung pada guru itu sendiri. Pembelajaran online memberikan kesempatan kepada siswa dan guru untuk belajar dan mengakses materi lebih fleksibel waktunya. Namun, sebaiknya pelaksanaan pembelajaran daring dilakukan sesuai waktu yang terjadwal setiap mata pelajaran yang telah disepakati dengan guru untuk capaian belajar sesuai rencana pelaksanaan pembelajaran yang telah didesian sebelum kegiatan belajar di mulai. Adapun pertanyaan angket yang diisi oleh peserta guru-guru di ilustrasikan pada Tabel 2 .

Tabel 2. Pertanyaan angket

\begin{tabular}{cllc}
\hline No & Pertanyaan & Jawaban Responden & Persentase \\
\hline 1. & Apakah sarana pembelajaran daring di & Sangat memadai & $3,6 \%$ \\
& sekolah anda memadai & Memadai & $45,6 \%$ \\
& & Cukup memadai & $35,7 \%$ \\
2. & Apakah siswa merasa mulai terbiasa & Terbiasa & $14,3 \%$ \\
& melakukan pembelajaran secara daring. & Belum terbiasa & $50,0 \%$ \\
& & Tidak Tahu & $46,4 \%$ \\
3. & Tanggapan siswa terhadap pelaksanaan & $3,6 \%$ \\
& pembelajaran daring & Sangat baik & $45,4 \%$ \\
& & Baik & $36,7 \%$ \\
& & Cukup baik & $17,9 \%$ \\
& Tidak baik & $0,0 \%$ \\
\hline
\end{tabular}

Pembelajaran daring bertindak sebagai salah satu jalur arternatif pada masa pendemi sekarang ini untuk memberikan materi kepada siswa. Dampaknya membuat para murid perlu waktu untuk beradaptasi dan mereka menghadapi perubahan baru yang secara tidak langsung akan mempengaruhi daya serap belajar mereka. Selain itu, siswa dan guru perlu sarana dan prasarana yang memadai di rumah maupun di sekolah. Fakta dilapangan, 46,4\% sarana pembelajaran daring di sekolah memadai. Hal ini artinya bahwa guru di berikan fasilitas untuk memberikan materi kepada siswa melalui belajar online. (Purwanto et al., 2020), fasilitas sarana dan prasarana sangat penting untuk kelancaran proses belajar mengajar, untuk pembelajaran online di rumahnya seharusnya disediakan dulu fasilitasnya seperti laptop, computer ataupun hand phone yang akan memudahkan murid untuk menyimak proses belajar mengajar online. Menurut (Pratama et al., 2020) kondisi ini akan semakin menyusahkan ketika guru atau siswa dengan tingkat pemahaman teknologinya masih rendah. Mereka sering mengeluhkan habisnya 
paket kuota internet. Selain itu, teknologi dianggap dapat membangun sikap instan bagi para penggunanya.

(Wahyono et al., 2020) beban belajar peserta didik tentunya harus diperhitungkan, terukur, baik secara materi maupun waktu. Guru tidak boleh semata-mata memberikan tugas, tetapi harus memperhitungkan secara matang. Guru tidak boleh lupa untuk mengapresiasi capaian peserta didik. Kurikulum yang fleksibel dan siap menghadapi pandemi juga dibutuhkan. Perubahan pola belajar dan mengajar tentu tak akan pernah terlepas dari peran guru (Collie et al., 2006); (Yusof, 2012); (Thien et al., 2014);(Zacharo et al., 2018), terlebih perubahan ke pola pembelajaran daring. Guru harus siap dengan berbagai kondisi pembelajaran dan kondisi siswa, termasuk perkembangan kehidupan di masyarakat (Abdullah, 2017); (Hammond \& Bransford, 2005); Dalam pembelajaran daring, guru memiliki peran penting terutama untuk memotivasi agar peserta didik tetap semangat mengikuti pembelajaran. Guru memberikan tugas yang menarik dan menyenangkan serta seluruh guru membuat sebuah video untuk memberikan semangat kepada peserta didik meskipun harus melaksanakan pembelajaran dari rumah (Putria et al., 2020). Dengan demikian, lambat laun siswa akan terbiasa melaksanakan pembelajaran daring. Hasil penelitian, 45,5\% siswa sudah terbiasa terhadap pembelajaran daring di era pandemi Covid-19 ini.

Wawancara yang digunakan dalam penelitian ini adalah jenis wawancara terstruktur terhadap 28 responden guru yang mengajar dibeberapa sekolah menengah pertama di Kab. Bandung yaitu Wawancara dilakukan dengan tujuan untuk memperdalam data yang diperoleh dari angket. Adapun hasil wawancara yang telah dilakukan kepada dua responden adalah sebagai berikut:

Beberapa yang harus dipersiapkan dalam pembelajaran daring berdasarkan jawaban responden meliputi: (1) RPP dan silabus pembelajaran daring, (2) bahan ajar melalui video pembelajaran yang dibuat oleh responden maupun mengunduh dari link youtube, (3) membuat bahan ajar melalui powerpoint interaktif, (4) Soal lathan melalui google form, (5) abseni online, (6) menyiapkan kuota internet dan leptop/HP, (7) Modul dan LKS, (8) Platform daring seperti zoom meeting, google meet, whatsapp grup, (9) penyampaian materi melalui $e$ learning, zoom meeting atau google meet, modul yang tentunya di desain sesuai dengan pembelajaran daring.

Pertanyaan selanjutnya, yaitu "menurut Anda bagaimana kualitas materi yang disampaikan oleh guru dalam kelas daring?". Pada umumnya, responden memberikan jawaban cukup baik materi yang di sampaikan oleh guru, dimana guru merancang bahan ajar sendiri agar siswa lebih memahami materi yang diberikan dan berusaha agar materi dapat tersampaikan dengan baik serta menyesuaikan kondisi siswa masing-masing sekolah. Media yang digunakan oleh responden dalam pembelajaran daring meliputi Powerpoint, video pembelajaran, Google classroom, YouTube, google from, Meeting zoom atau google meet, WhatsApp group, Google classroom, Gawai, LKS, buku paket sekolah, dan video pembelajaran serta tiktok. Sejalan dengan (Wahyono et al., 2020), materi pelajaran yang lebih spesifik dapat disediakan melalui konten yang dapat diunduh (misalnya menggunakan laptop dan smartphone) dan komunikasi melalui telepon 
(misalnya video conference dan komunikasi video call satu-satu). (Purwanto et al., 2020) juga mengungkapkan bahwa fasilitas ini sangat penting untuk kelancaran proses belajar mengajar. Sejalan dengan (Nuraeni et al., 2020) bahwa "Online learning allows students to have free time to study so they can study whenever and wherever". Guru perlu sekiranya menyiapkan rencana pembelajaran yang disesuaikan dengan kondisi pandemi Covid 19 ini agar tercapai tujuan pembelajaran yang diharapkan. Pengembangan pembelajaran merupakan bagian yang sangat penting dan tentunya sangat menentukan tercapainya tujuan pembelajaran itu sendiri untuk menyajikan pembelajaran yang baik dan sistematis serta dapat merancang suatu konsep pembelajaran (Zein, 2016).

Pertanyaan selanjutnya, yaitu "kendala atau hambatan apa sajakah yang guru temui selama pembelajaran daring?". Hasil dari jawaban responden yaitu (1) tidak semua siswa memiliki handphone, leptop ataupun computer, (2) keterbatasan kuota internet yang dimiliki oleh siswa dan jangkauan sinyal operator (3) ada bebeerapa siswa yang kurang aktif dan tidak mengumpulkan tugas; (4) partisipasi kehadiran dan respon siswa yang kurang pada saat pembelajaran; (5) latar belakang siswa; (6) pengumpulan tugas yang masih sulit dilakukan oleh siswa sehingga sering terlambat dalam mengumpulkan tugas; (7) Kurangnya aturan yang ketat bagi siswa yang tidak mengikuti atau mengumpulkan tugas saat pembelajaran daring; (8) rendahnya penguasaan teknologi yang digunakan dalam pembelajaran daring, misalkan siswa hanya bisa menggunakan whatsapp saja ketika diberikan google classroom sangat kebingungan.
Purwasih., et al (2020) tuntutan era revolusi industry 4.0 yang mengharuskan individu beradaptsi sekaligus terlibat terampil menggunakan dan memanfaatkan teknologi untuk aktivitas pendukung belajar.

Hambatan dalam kegiatan daring pada umumnya adalah peserta didik masih kurang paham dalam menggunakan aplikasi yang digunakan dalam belajar online dan koneksi internet yang lambat pada daerah tertentu. Solusi yang diberikan oleh sekolah atau guru adalah guru melaksanakan home visit di sela sela pembelajaran daring dengan memperhatikan protokol kesehatan, guru menyediakan tugas dan materi yang sudah di prin untuk diambil oleh siswa ke sekolah, dan guru menghubungi siswa satu persatu lewat telepon atau whatsapp. Pembelajaran daring ada dampak positif dan ada dampak negatif. Sebagaimana pendapat (Dewi, 2020) yang mengatakan bahwa pembelajaran daring merupakan suatu inovasi dalam dunia pendidikan dalam menjawab tantangan ketersediaan variasi sumber belajar. Sedangkan penelitian dari (Wahyono et al., 2020); materi pembelajaran yang disampaikan oleh guru kurang maksimal, sehingga menjadikan materi tidak tuntas dan penggunaan media pembelajaran dalam pembelajaran daring juga dirasa tidak maksimal. Selain itu, kejenuhan dan rasa bosan dialami oleh siswa untuk mengerjakan tugas dan menjadikan pengumpulan tugas menjadi sangat terlambat sehingga menjadikan guru sulit melakukan penilaian.

Selanjutnya, solusi pembelajaran daring yang diberikan oleh guru adalah membuat video pembelajaran yang menarik, jika siswa tidak masuk saat pembelajaran daring, guru menyiapkan LKS dan materi disekolah yang bisa 
diambil oleh siswa dan dipelajari dirumah; (5) guru melakukan pendekatan dengan melalui video call grup; (6) Mencari tempat yang jaringannya baik, jika ada anak yang terkendala jaringan, misal tidak dapat bergabung melalui Google Meet, maka kita menyiapkan materi juga untuk yang tidak dapat bergabung Google Meet. Untuk yang sering terlambat mengerjakan tugas, biasanya menghubungi nya secara langsung agar segera mengerjakan tugas, atau melalui guru pamong yang diteruskan kepada wali kelas dan sampai ke orangtua siswa.

Dengan diadakannya luring untuk yang tidak memiliki handphone dengan waktu yang bergilir melakukan evaluasi pembelajaran secara tatap muka, untuk mereview materi yang disampaikan secara daring. Diadakan luring tetap dengan protokol kesehatan untuk siswa yang kesulitan mengumpulkan tugas dan tidak mempunyai handphonne, diadakan secara bergantian dan sesuai dengan jadwal mata pelajaran. Selain itu, diberikan modul pembelajaran yang dimana bisa di pelajari oleh siswa secara mandiri. Karena media yang tepat dapat berfungsi secara efektif dan interaktif sebagai penghubung antar siswa dengan guru sehinga capaian pembelajaran tercapai (Pratiwi \& Silalahi, 2021).

Fasilitas yang menunjang untuk pembelajaran tetapi memunculkan rasa malas untuk mengerjakan tugas merupakan faktor penghambat yang belajar daring yang dialami oleh siswa. Faktor yang selanjutnya adalah masih banyak orang tua yang bekerja sehingga tidak dapat sepenuhnya membimbing peserta didik dalam pembelajaran. Untuk orang tua yang sibuk bekerja guru memberikan pelonggaran waktu dalam pengumpulan tugas. (Rigianti,
2020), hasil penelitiannya menunjukkan bahwa pada minggu awal kegiatan pembelajaran daring, orangtua memberikan perhatian penuh terhadap anaknya. Namun pada minggu kedua dan seterusnya, pengawasan dari orang tua mulai berkurang. Hal ini terjadi karena pada saat yang sama, orang tua siswa juga harus membagi waktu untuk bekerja dan mengurus rumah. Sehingga yang terjadi adalah guru mengirimkan tugas dan orang tua mengirimkan hasil pekerjaan anak. Tanpa adanya pengawasan dalam belajarnya sehingga anak belajar sesuai kemampuannya.

Fakta dilapangan, kemampuan dan keinginan terkadang tidak sejalan dan ada kesenjangan. Hasil review penelitian menunjukkan bahwa adanya kesenjangan antara ideal dan kenyataan dalam mengintegrasikan interaksi sebagai bagian dari aktivitas online dalam pembelajaran. Proses belajar tidak dapat mencapai potensi penuhnya sampai siswa mempraktekkan apa yang mereka pelajari. Terkadang, konten online semuanya teoretis dan tidak membiarkan siswa berlatih dan belajar secara efektif (Dhawan, 2020).

Cara guru dalam memberikan motivasi adalah dengan memberikan tugas yang menarik dan menyenangkan serta seluruh guru membuat sebuah video untuk memberikan semangat kepada peserta didik meskipun harus melaksanakan pembelajaran dari rumah. Pembelajaran dalam bentuk teknologi atau berbantuan perangkat komputer dan internet yang berbasis ICT memberikan ruang gerak dan kesempatan kepada siswa untuk belajar kreatif dan aktif memahami materi ajar (Purwasih, Jumiatin, et al., 2020).

Impilikasi penelitian ini memperlihatkan adanya perbedaan penggunaan media untuk implementasi 
pembelajaran daring oleh guru SMP. Selain itu, kemampuan guru dalam melaksanakan pembelajaran daring menggunakan media berbasis ICT diperlukan skill khusus untuk menggunakannya. Hal ini dapat dijadikan sebagai bahan pertimbangan sekolah agar guru diberikan pelatihan khusus berkenaan penggunaan ICT dalam pembelajaran daring untuk menciptakan pembelajaran yang menarik.

\section{KESIMPULAN DAN SARAN}

Berdasarkan penelitian yang telah dilakukan dapat disimpulkan bahwa (1) implementasi pembelajaran daring dilakukan dengan menggunakan aplikasi online seperti google meet, google classroom dan E-learning; (2) Setiap sekolah menyiapkan sarana dan prasarana pembelajaran daring dan melakukan bimbingan teknis kepada guru agar bisa menggunakan teknologi modern dalam pembelajaran untuk meningkatkan kualitas peserta didik. (3) Hambatan/kendala pembelajaran daring baik dari aspek sumber daya manusia maupun sarana-prasarana, diantaranya jaringan internet, tidak memiliki handphone,leptop atau komputer, orang tua tidak bisa mendampingi belajar, guru dan siswa masih ada yang belum bisa menggunakan teknologi, dan partisipasi serta motivasi siswa yang rendah. Untuk mengatasi hambatan tersebut, solusi yang diberikan meliputi home visit, membuat modul atau LKS pembelajaran yang diprintkan untuk diambil oleh siswa ke sekolah, guru membuat video pembelajaran yang menarik dan menghubungi siswa satu persatu melalui telepon atau whatsapp, serta ada sekolah yang melaksanakan pembelajaran secara luring dan daring terjadwal secara bergantian setiap pekannya.
Saran untuk langkah penelitian selanjutnya yang berhubungan dengan penelitian ini, disarankan untuk meneliti sikap siswa dan orang tua terhadap pembelajaran daring.

\section{DAFTAR PUSTAKA}

Abdullah, R. (2017). Pembelajaran Dalam Perspektif Kreativitas Guru Dalam Pemanfaatan Media Pembelajaran. Lantanida Journal, 4(1), 35. https://doi.org/10.22373/lj.v4i1.18 66

Basilaia, G., \& Kvavadze, D. (2020). Transition to Online Education in Schools during a SARS-CoV-2 Coronavirus (COVID-19) Pandemic in Georgia. Pedagogical Research, 5(4). https://doi.org/10.29333/pr/7937

Chakraborty, M., \& Muyia Nafukho, F. (2014). Strengthening student engagement: What do students want in online courses? European Journal of Training and Development, 38(9), 782-802. https://doi.org/10.1108/EJTD-112013-0123

Collie, R. J., Shapka, J. D., \& Perry, N. E. (2006). Predicting teacher commitment: The impact of school climate and socialemotional learning. Psychology in the Schools, 3, 1034-1048. https://doi.org/10.1037/a0029356. PREDICTING

Dewi, W. A. F. (2020). Dampak COVID-19 terhadap Implementasi Pembelajaran Daring di Sekolah Dasar. Edukatif: Jurnal Ilmu Pendidikan, 2(1), 55-61. https://doi.org/10.31004/edukatif. v2i1.89

Dhawan, S. (2020). Online Learning: A Panacea In The Time of COVID- 
DOI: https://doi.org/10.24127/ajpm.v10i2.3545

19 Crisis. Journal of Educational Technology Systems, 49(1), 5-22. https://doi.org/10.1177/00472395 20934018

Hammond, L. D., \& Bransford, J. (2005). Preparing Teachers Design of Teacher Education Programs.Pdf (pp. 390-441).

Imania, K. A., \& Bariah, S. K. (2019). Rancangan Pengembangan Instrumen Penilaian Pembelajaran Berbasis Daring. Jurnal Petik, 5(1), 31-47. https://doi.org/10.31980/jpetik.v5i 1.445

Jamilah, J. (2020). Guru profesional di era new normal: Review peluang dan tantangan dalam pembelajaran daring. Premiere Educandum: Jurnal Pendidikan Dasar Dan Pembelajaran, 10(2), 238.

https://doi.org/10.25273/pe.v10i2. 7494

Najeemah, M. Y. (2012). School climate and teachers, commitment: A case study of Malaysia. International Journal of Economics Business and Management Studies, 1(2), 65-75.

Nuraeni, L., Purwasih, R., \& Mutakim, J. (2020). IKIP Siliwangi student's perceptions of online teaching and learning process during COVID-19 pandemic? Journal of Physics: Conference Series, 1657(1). https://doi.org/10.1088/17426596/1657/1/012084

Pratama, L. D., Lestari, W., \& Astutik, I. (2020). Efektifitas Penggunaan Media Edutainment Di Tengah Pandemi Covid-19. AKSIOMA: Jurnal Program Studi Pendidikan Matematika, 9(2), 413-423. https://doi.org/10.24127/ajpm.v9i 2.2783
Pratiwi, I. R., \& Silalahi, P. (2021). Pengembangan Media Pembelajaran Metematika Model Blended Learning Berbasi Moodle. AKSIOMA: Jurnal Program Studi Pendidikan Matematika, 10(1), 206-218.

Purwanto, A., Pramono, R., Asbari, M., Santoso, P. B., Wijayanti, L. M., Choi, C. H., \& Putri, R. S. (2020). Studi Eksploratif Dampak Pandemi COVID-19 Terhadap Proses Pembelajaran Online di Sekolah Dasar. EduPsyCouns: Journal of Education, Psychology and Counseling, 2(1), 1-12. https://ummaspul.ejournal.id/Edupsycouns/article/vie w/397

Purwasih, R., Jumiatin, D., \& Aripin, U. (2020). Pemerdayaan Guru-Guru MTs Cahaya Harapan Melalui Kegiatan Transfer IPTEK EMathgogy Menggunakan Pendekatan Revolusi Industry 4.0. J-ADIMAS (Jurnal Pengabdian Kepada Masyarakat), 8(1), 3741.

Purwasih, R., Komala, \& Santana, F. D. T. (2020). Persepsi Mahasiswa Calon Pendidik terhadap Pembelajaran Daring Berbasis ICT pada Masa Pandemik Covid19. Edumatica:Jurnal Pendidikan Matematika, 10(02), 10-18.

Putria, H., Maula, L. H., \& Uswatun, D. A. (2020). Analisis Proses pembelajaran Dalam Jaringan (DARING) Masa Pandemi COVID-19 pada Guru Sekolah Dasar. Jurnal Basicedu, 4(4), 861-872.

https://doi.org/10.31004/basicedu. $\mathrm{v} 4 \mathrm{i} 4.460$

Rigianti, H. A. (2020). Kendala Pembelajaran Daring Guru Sekolah Dasar Di Kabupaten 
DOI: https://doi.org/10.24127/ajpm.v10i2.3545

Banjarnegara. Elementary School, 7(2), 1-9.

Thien, L. M., Abd Razak, N., \& Ramayah, T. (2014). Validating Teacher Commitment scale using a Malaysian sample. SAGE Open, 4(2).

https://doi.org/10.1177/21582440 14536744

Wahyono, P., Husamah, H., \& Budi, A. S. (2020). Guru profesional di masa pandemi COVID-19: Review implementasi, tantangan, dan solusi pembelajaran daring. Jurnal Pendidikan Profesi Guru, 1(1), 51-65. http://ejournal.umm.ac.id/index.p hp/jppg/article/view/12462

Waruwu, M. (2020). Studi Evaluatif Implementasi Pembelajaran Daring Selama Pandemi Covid19. Jurnal Administrasi Pendidikan, 27(2), 288-295. https://doi.org/10.17509/jap.v27i2 .27081

Zacharo, K., Marios, K., \& Dimitra, P. (2018). Connection of teachers' organizational commitment and transformational leadership. A case study from Greece. International Journal of Learning, Teaching and Educational Research, 17(8), 89-106. https://doi.org/10.26803/ijlter.17.8 6

Zein, M. (2016). Peran Guru dalam Pengembangan Pembelajaran. Jurnal Inspiratif Pendidikan, 5(2), 274-285.

http://103.55.216.56/index.php/In spiratifPendidikan/article/view/3480 